eminent engineers and inventors, and we understand it has already taken steps which should ensure the proper recognition of the centenary of the great Cornish engineer Richard Trevithick, who died in 1833. Trevithick died in poverty at Dartford and lies in an unknown grave, but in 1883 , through the action of the Institution of Civil Engineers, a window in his memory was erected in Westminster Abbey. He was one of the most gifted inventors who ever lived, while as an engineer he was the pioneer of the high-pressure steam engine, and this at a time when the authority of Watt, who would have nothing to do with high pressures, was almost world-wide.

\section{An Empire Museum Survey}

Amongst many topics dealt with by Sir Henry Miers in his fourth presidential address to the Museums Association was that of an Empire Museum Survey. A few years ago the possibility of so great a venture would have occurred to no one; now the Survey itself is far advanced towards accomplishment, thanks to the initiative and energy of Sir Henry Miers himself. It began with the Carnegie United Kingdom Trust survey of the museums of the British Isles; it was continued with rapidity when the Carnegie Corporation of New York, in addition to all it is doing for the United States, expressed its willingness to expend certain funds allocated for expenditure within the British Empire (exclusive of the British Isles) upon such a scheme. In 1931, Sir Henry Miers and Mr. Markham visited 121 museums and galleries in Canada; early this year they visited all the museums they could discover in the Union of South Africa and in Rhodesia, as well as many others encountered on the return journey by Khartoum, Cairo, and Port Said. This year also a survey of museums in British possessions in the Mediterranean Sea was carried out by Alderman Squire and Mr. Herdman. So that in a year, from June 1931 until June 1932, two-thirds of the Empire Survey has been completed; and now there remain only to be tackled the Commonwealth of Australia, Tasmania, New Zealand, the West Indies, and a few almost inaccessible places like the Falkland Islands.

\section{Mississippi Floods}

THE disastrous floods in the Mississippi basin in the spring of 1927 have led to various suggestions for preventing their recurrence. These are critically examined by M. O. Messerly in a paper entitled "Les Travaux de defénse du Mississippi " in Matériaux pour l'etude des calamités, No. 3, année 1931 (1932). Several of the proposals would probably lead to effective defence, but are not feasible on the score of cost. The construction of reservoirs on the tributary streams would be useful but very expensive. In industrial districts, however, such reservoirs would have a local use, in addition to their protective value. Setting back the embankments along the lower reaches, if done on a large enough scale, would help considerably, but is scarcely practicable. Dredging of the bed would be effective, but only if continuous and on a very large scale. Afforestation might help in checking the flow of rainfall to the rivers, but even vast schemes might afford only small relief. In any case, the effect would not be felt for a generation or more. The most practical measures seem to be the raising and strengthening of the embankments at certain places, the construction of new drainage channels parallel with the main stream, and the straightening of the river in places to facilitate the flow of water.

\section{Duck Decoy Ponds in Europe}

Science Service (Washington, D.C.) publishes a Berlin message concerning the slaughter of migratory ducks by decoy ponds in Europe. In Germany there are at present eleven decoys, with an average annual catch of 40,000 ducks; in Denmark two, with an average of 12,000; in Belgium four, average not stated. England is said to have twenty-one, capturing about 600 ducks; and Holland to have the greatest number of decoys, 145, having an average yearly catch of 300,000 ducks-a number until now suppressed in the interest of the Dutch canning industry, which has built up a profitable export trade upon the proceeds of the decoys. The finding of ringed birds shows that the ducks caught in Holland come largely from Scandinavia and Finland, and the fear is that the supply will eventually fail under this serious annual drainage. The open season lasts from July 27 until Feb. 14, or even March 13, and a shortening of this period would have a good effect, but it is said that the Dutch Government is unwilling to interfere with a profitable home industry. Nevertheless, an effort will be made at the International Conference, to have the open season reduced to a period from Sept. 15 until Jan. 31.

\section{Bibliography of Newcastle-upon-Tyne Local Records}

As all interested in bibliographical matters no doubt know, Newcastle-upon-Tyne possesses an excellent public library, rich not only in the books generally found in such institutions, but also particularly in works of local interest. Having regard to the fact that Newcastle-upon-Tyne and the district of which it is the centre have taken such a prominent part in the invention and the development of technical methods and appliances of great industrial importance, it is obvious that these records of local doings necessarily appeal to a far wider public, and the librarian, Mr. Basil Anderton, has done well in publishing a "Catalogue of Local Records". The eatalogue falls into two main divisions, namely, an author list and a subject list, together with certain appendixes which are perhaps of more strictly local interest. The subject list will probably be the one that will be more generally consulted, and it contains material of the greatest value, especially to the historian of matters of technological or sociological import. It need scarcely be said that in a coalmining centre like Newcastle-upon-Tyne, maps of the coal mines and royalties of the surrounding district play an important part, and give information of the utmost value to students of the development of the coal-mining industry. The catalogue appears to be very well executed, is well printed and published, and will form a valuable and useful addition to British bibliography.

\section{Progress of the Ordnance Survey}

The Report on the Progress of the Ordnance Survey for the year ending March 31, 1932, directs attention to the steadily increasing sale of small-scale maps, particularly the one-inch scale. This is no doubt due 